\title{
Universal chronicles in Arabic before c. 900
}

\section{Ann Christys*}

Abstract: This paper uses two Arabic chronicles of the mid ninth to early tenth centuries the History of Ibn Habīb and the History of the Prophets and Kings of al-Tabari - to illustrate the development of the message of the Qur'ann into chronological narratives that may be read as salvation history. The paper also briefly considers their place within the Islamic historiographical tradition and whether comparisons may be made with contemporary Christian historiography.

Keywords: Ibn Habìb, al-Ṭabarī, Qur'ān, hadìth, salvation history

Several historians active in the first three centuries of Islam wrote, or were said to have written, chronicles that began with Creation and extended to their own times and encompassed the Islamic and sometimes also the non-Islamic world. ${ }^{1}$ They appear to fit comfortably into the category of world or universal history. ${ }^{2}$ Comparison with works from the Early Medieval West that have been placed in the same category ${ }^{3}$ reveals the same concern for chronology and the computation of time, imposed on a framework of Old Testament narratives of prophets and their descendants and of the rise and fall of empires. The focus of the latter part of many of these histories on the life and teachings of the prophet Muhammad, the early Islamic conquests and the reigns of the caliphs gives a providential tone to the narrative, which was sometimes made explicit. Paradoxically, however, to label all these texts as universal chronicles is not only to invent a category that their authors would not have recognized, for even the designation "history ( $t a^{\prime} r i \bar{k} h$ ) is anachronistic. This paper uses two Arabic chronicles of the mid ninth to early tenth centuries - the History of Ibn Habib (d. 853) and the History of the Prophets and Kings of al-Ṭabari (d. 923) - to illustrate the development of chronological, "universal« narratives of the past within Islam.

Unlike the Jewish and Christian holy books, the Qur'ān is difficult to read as a narrative history of the chosen people. ${ }^{4}$ Although the Qur'ann considers Creation, the lives of the prophets, culminating with Muhammad and the early years of Islam, and anticipates the Day of Judgement, all aspects of the past and future are co-existent and the story is not told in a linear fashion. The sacred text is a series of moral messages to which episodes from history are added wherever appropriate to point up these teachings. Some time after the consolidation of the text of the Qur'an - it is not clear when - a second source of knowledge about the past

* Correspondence details: Ann Rosemary Christys, Independent scholar, 2, Moseley Wood Farm, Smithy Lane, Leeds LS16 7NG, UK, email: ann@clovis.demon.co.uk

1 Khalidi, Arabic Historical Thought, 33.

2 Radtke, Weltgeschichte und Weltbeschreibung.

3 Wood, Universal Chronicles.

4 Donner, Narratives of Islamic Origin, 80; Khalidi, Arabic Historical Thought, 8 ff.; Neuwirth, Qur'an and History; Robinson, Islamic Historiography, 43. 
evolved. The teachings recorded in the Qur'ann were supplemented with hadith: the sayings of Muhammad, his Companions and other Muslims of the generations of the Islamic conquests. These were remembered and, from the beginning of the ninth century, recorded in writing, authenticated by isnāds - long chains of names going back to the source of the citation. Much has been written on hadith, which cannot even be summarised here. ${ }^{5}$ Even in the early centuries of Islam, the material was controversial, and repeated attempts were made to distinguish between false and true hadith by validating their transmitters. Furthermore, hadith overlapped with akhbār - >accounts`, sometimes translated as >historical traditions « - which also narrated episodes from the past, but were usually supported by much shorter isnāds.

Although hadith and akhbär were a vast resource of information, it may have been some time before this was added to the knowledge of the past assembled in the Qur'an to convert it into a chronological narrative. ${ }^{6}$ Nor was this process recognised as forming a separate category of knowledge within Islam. As late as the ninth century, the term ta'rikh, which was sometimes used for what we would now call »history«, was used mainly to indicate the date of an event. In 987-8 Ibn al-Nadim, the son of a bookseller in Baghdad, drew up a catalogue of all the books known to him; some of these are extant; many others have disappeared. The first section of the third chapter of his catalogue is allocated to raccounts ( $a k h b \bar{a} r$ ) of the historians (akhbäriyyin), genealogists and preservers of biographies and events (așhāb alsiyar wa-l-ahädith), with the names of their books.$^{7}$ Although a few of the works are listed as "ta'rikh " Ibn Nadim did not gave a single name to this category; nor did he list all the chronological narratives or lists, however labelled, in this section; many appear in other sections of the catalogue with more famous works by their authors on theology, law or other matters. Conversely, works labelled "ta'rìkh « could in practice cover a wide range of subjects. One of the earliest historians writing in Arabic whose name was recorded is Ibn Ishāq (d. 760s), the author of a Life of the prophet Muhammad that survives only in late medieval manuscripts of a version by Ibn Hishām (d. 834). Many different titles were given to Ibn Ishāa's work when it was cited in later centuries, but they suggest that he prefaced his Life of the Prophet with a narrative or a collection of hadith on Creation called The Beginning (Kitäb al-Bad, Kitäb al-Mubtadä'); this does not survive, although an attempt has been made to reconstruct it from a considerable number of citations of it by later authors, in particular al-Tabarī. ${ }^{8}$ Similarly, the titles given to other eighth-century authors such as Wahb b. Munabbih (d.728) point towards the writing of histories from Creation, but the citations from these authors in late medieval manuscripts cannot always be attributed with confidence. ${ }^{9}$ Turning to the works that survived, although often only in much later manuscripts, gives a smaller number of texts, even though some of them are enormously long and wide-ranging. Radtke listed eighteen Islamic universal histories written in Arabic before 1500, nearly all of them in the later Middle Ages. ${ }^{10}$

Ibn al-Nadìm, Kitāb al-Fihrist, vol. 1/2, 277; Dodge's translation adds to the confusion between hadith and akhbär by translating akhbār, aḥdāth and ahädith as shistorical traditions‘. 
The History attributed to Ibn Habīib ${ }^{11}$ poses problems of dating. Ibn Habỉb was better known to his contemporaries as a legal scholar than as a historian and also composed works in many genres, several of which have survived. He was born in Elvira, near Granada and spent some years in Egypt, before returning to al-Andalus, where he served the Umayyads in Cordoba. ${ }^{12}$ The History survives only in a single manuscript, dated by the copyist to 695/1295-6. It cannot be the work of Ibn Habib alone, since it includes annals that continue to the 880 s, thirty years after his death. It was not uncommon for continuations of medieval Arabic texts to be known by the name of the first or most important author. Most scholars consider Ibn Habib's History to be a continuation, or even a set of notes, by one of his students, which is how it will be treated here, although Makki argued that changes were made to the text in the eleventh century. ${ }^{13}$ The History begins 50,000 years before the Creation of the world, when Allāh decrees the measures of good and evil ${ }^{14}$ and continues with an account of the prophets from Adam to Muhammad and a summary of the expansion of Islam up to the caliphate of al-Walid I (705-715). After this, the focus narrows to al-Andalus, with a detailed narrative of the conquest of Hispania in 711 and a short annalistic account of the Umayyad governors and emirs of al-Andalus. Ibn Habib's sources are not immediately obvious. He cited only three written texts: Ibn Hisham's version of Ibn Ishāa's biography of the Prophet and the works of two other historians that are no longer extant. ${ }^{15}$ He included hadiths, and these may perhaps have come from his own hadith compilations which have yet to be edited. ${ }^{16}$ Although Ibn Habib often used hadith that were regarded as reliable, as we shall see, he did not follow the orthodox procedure when citing them, often leaving them unattributed, or with a truncated chain of authorities. For this he was censured by one of his biographers, Ibn al-Faradịi (d. 1012), who also complained that Ibn Habỉb could not distinguish between true and false hadiths. ${ }^{17}$ Such criticisms were commonly levelled at scholars who recounted episodes from history, who were denigrated as akhbäris - reporters of anecdotes rather than transmitters of truth.

In the surviving manuscript, the History ends with a prediction of the destruction of al-Andalus, followed by hadiths on the destruction of sinful nations and biographies of some of the transmitters of these hadiths. Thus Ibn Habib, or his continuator, realized the purpose that he had stated towards the beginning of the text:

I begin it with Adam [and] I mention all the prophets and kings who inhabited the world and their affairs and their history [akhbār] if God wishes and... what God worked for them until the time of the Prophet, peace and blessings upon him ... and how the caliphs followed after him in their history and stories about them and their lives until the time of Walīd ibn 'Abd al-Malik ibn Marwān, may God have mercy on him. Then I come to the conquest of al-Andalus and the arrival there of Tăariq, mawlā of Mūsā ibn Nuṣayr and I mention the number of her governors and those who will govern her until she is destroyed and what will

11 Ibn Habīb, Kitab al-Ta'rikh, ed. Aguadé.

12 Al-Khushanī, Ajbār al-Fuqahā', ed. Ávila and Molina, 245-253.

13 Makki, Egipto y los orígines, 207.

14 Ibn Habīb, Kitab al-Ta'rikh, ed. Aguadé, 13.

15 Ibn Habīb, Kitab al-Ta'rikh, ed. Aguadé, 100.

16 Ibn Habīb, Kitab al-Ta'rikh, ed. Aguadé, 66.

17 Ibn Habīb, Kitab al-Ta'rikh, ed. Aguadé, 42.

medieval worlds $\bullet$ No. $1 \cdot 2015 \cdot 61-70$ 
happen after the destruction until the hour [of the Last Judgement] with the traditions and the signs [of the end of the world] if God wishes it comes. ${ }^{18}$

At around the time that Ibn Habīb's pupil assembled his teacher's History, al-Tabarī' opened his History of the Prophets and Kings on a providential note:

In this book of mine I shall mention whatever information has reached us about kings throughout the ages from when our Lord began the Creation of His Creation to its annihilation. There were messengers sent from God, kings placed in authority, or caliphs established in the caliphal succession. God had early on bestowed his benefits and favours upon some of them. They were grateful for His favours, and He thus gave them more favours and bounty in addition to those bestowed by Him upon them in their fleeting life, or He postponed the increase and stored it up for them with Himself. There were others who were not grateful for His favours, and so He deprived them of the favours He had bestowed upon them early on and hastened for them His revenge. There were also others who were not grateful for His favours: He let them enjoy them [only] until the time of their death and perdition. ${ }^{19}$

Like Ibn Habỉb, al-Ṭabarī wrote on many subjects. He too was a noted legal scholar and his exegesis (Tafsìr) of the Qur'ān is still consulted. Born in Āmul, the capital of Ṭabaristān, he spent many years as a wandering scholar before settling in Baghdad. The pre-Islamic section of al-Tabarìs History is structured both by the Old Testament prophets and by a chronological account of the Persian Empire. A biography of the prophet Muhammad is followed by annals of the caliphs, ending in 302/914-15. The work aimed for completeness, to judge from its title as reported by one of al-Tabari's biographers: History and deeds of all the Prophets and Kings from the earliest times ${ }^{20}$. Al-Tabari claimed that it was trustworthy, citing straditions and reports which I have transmitted and which I attribute to their transmitters ${ }^{21}{ }^{2}$ He clearly relied on written sources, rather than oral transmission; the same biographer remarked: >Because of his concern for scholarly research, he had his books all laid out on one side of his residence, then went through them for the first [time] one by one, in the process carrying them to the other side, until he was through with them; then he studied them again and returned them to their original places. ${ }^{22} \mathrm{Al}$-Tabarì's method of assembling chunks of narrative, often giving variant accounts of the same events, ${ }^{23}$ with each preceded by a long chain of isnāds made for a long and often tedious work. No complete manuscript of the History survives. The modern versions are a composite of several manuscripts produced for the Leiden edition of 1879-1901; a new edition, published in Cairo in 1969, collated this edition with manuscripts from the library of the Topkapi palace in Istanbul. The editorial treatment of the manuscripts, paired with its sheer size, complicate the interpretation of the History.

Given the uncertainty in both the date and the original forms of the Histories of Ibn Habib and al-Tabarī, it is impossible to say which came first, and whether one was a direct influence on the other. The two historians moved in similar scholarly circles, although it is unlikely that they ever met. Both men spent several years in Egypt. Ibn Habib was a contemporary

19 Al-Ṭabarī, Ta'rīkh, vol. 1, ed. Barth, 5; trans. Rosenthal, History of al-Tabari, 168.

20 Ta'rīkh al-rusul wa-l-mulūk wa-akhbāruhum wa-man kān fĩ zamān kull wāhìd minhum; Yā'qūt, Irshād VI, 68, trans. Rosenthal, History of al-Tabari, 131.

21 Al-Ṭabarī, Ta'rīkh, vol. 1, ed. Barth, 6, trans. Rosenthal, History of al-Tabari, 170.

22 Yāqūt, Irshād, vol. 6, 68, trans. Rosenthal, History of al-Tabari, 131.

23 Franz, Kompilation in arabischen Chroniken, 7-16. 
of the historian Ibn 'Abd al-Hakam (d.871) and both studied with his father, a famous legal scholar. Al-Tabarī was in Egypt c.867-870, where he may have met Ibn 'Abd al-Hakam and he could have read the latter's Conquest of Egypt, a history of Egypt from pre-Islamic times which is authenticated by long chains of isnäds - although he cited Ibn 'Abd al-Hakam only once. ${ }^{24}$ The similarities in approach, if not the length of both Histories also suggest that they used a common written model, perhaps The Beginning attributed to Ibn Ishāa, mentioned above. Both historians developed their history of salvation within the framework of the measurement of time. It seems that, as in the Christian tradition, sthe recording of the passage of time was an end in itself... [which] afforded the possibility of rare glimpses of the workings of Providence ${ }^{25}{ }^{25} \mathrm{Al}$-Tabari began his work with a long discussion on the meaning of time. ${ }^{26}$ Ibn Habib divided time into ages that echo the Christian tradition; his calculation, which put the birth of Jesus at c. 6,000, makes this some 500 years later than the most commonly cited Christian dating; the birth of Muhammad is dated 500 years later and both traditions envisage that the End of the World may be some 500 years after the arrival of their most significant holy figure:

Adam lived for 1,000 years and between him and Noah were 1,000 years, which is 2,000 years. Noah lived for 1,000 years and between him and Abraham were 1,000 years, which is 4,000 years. Another 1,000 years passed until Allāh sent down the Torah to Moses, which is 5,000 years. Between the Torah and the Psalter (Zabür) were 500 years and between the Psalter and the Gospels (Injill) 500 years and 6000 years were over. And from Jesus ('Isā) to Muhammad - Peace and blessings upon him - a full 500 years passed. I will describe what elapsed during the remaining 500 [years], God willing. According to Ibn Habīb 200 years remain of the 500 years up to the end of the 7000 years [but] according to other narratives there are more [years remaining to the End of the World]. ${ }^{27}$

Both Ibn Habìb and al-Tabarī emphasised the direction of time's arrow by expanding the Qur'anic narrative with hadith. The section on pre-Islamic history in both authors, built up mainly from the Qur'ān but also from the Old Testament, either as direct quotation or as inter-textual echoes ${ }^{28}$ is expanded with narratives derived from the so-called "Stories of the Prophets" (Qisas al-anbiyā'), a popular genre of fantastic stories and miracles that some scholars included in hadith, but which later Islamic scholars rejected. ${ }^{29}$ These stories were enlivened with hadith Qudsi: the direct speech of God, Jesus and other prophets. Thus several anecdotes were added to the Qur'anic account of the Flood and the building of Noah's Ark, Ibn Hābỉb described the animals going into the Ark and reported that Satan also entered the Ark by grabbing hold of the donkey's tail $;^{30}$ al-Tabari gave a slightly different version of events. ${ }^{31}$ Although comical, the story may have helped point the moral of that God's punishment for man's wickedness was not exhausted by the Flood. Both authors, however, supplemented this account with an anecdote that was not only unedifying but apparently ludicrous,

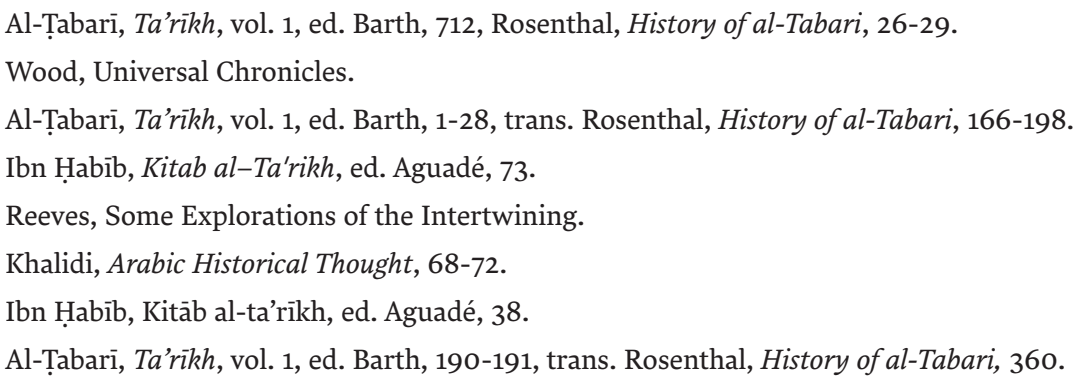


about the accumulation of dung in the Ark, and the miraculous appearance of an elephant, who managed to dispose of it. ${ }^{32}$ In both the Histories, some of the anecdotes believed to derive from the popular folk tales are also supported by hadith - and, in the case of al-Tabari, by long isnads. The hadith on the dung and the elephant has an isnäd going back to Muhammad's companion Ibn Abbās; he described a conversation between Jesus and his disciples about the Ark during which Jesus raised Hām from the dead so that he could describe it to them. ${ }^{33}$ The credibility of the transmitters of this material might be questioned; the method, however, was undisputedly orthodox. There are far fewer of the stories of apparently popular origin in the last section of al-Tabarì's History, the age of the caliphs, but Ibn Habib included several in his account of the conquest of al-Andalus, including a description of the House of Bolts where the Visigothic king Rodrigo saw portraits of the men who would overthrow them, together with anecdotes relating to the presence of king Solomon in the peninsula.

Al-Tabari was said to have written his History towards the end of his life, and at night, as though he had taken leave of the critical faculties he used in the compilation of his legal and religious works. ${ }^{34}$ Ibn Habïb's History has been dismissed as nugatory, following Dozy's verdict in the nineteenth century that it was simply a collection of fables. ${ }^{35}$ This judgement ignores the parallels between the History and Ibn Habìb's writings in other genres, which can be used to interpret his stories of the conquest of the peninsula as, amongst other things, a comment on its legal standing as a jiha $\bar{d} .{ }^{36}$ Furthermore, some of the hadiths that al-Tabari and Ibn Habìb used to validate their Histories were those that al-Ṭabari had used in his exegesis of the Qur'an, where he cited sayings of the Prophet to expound obscurities in the sacred text. One of these hadiths concerning the creation of the Pen, which al-Tabari discussed at length in the Tafsir, is cited at the beginning of Ibn Habib's History:

[Ibn Habib] related to us from Asad from Nașr ibn Ṭariff from Sa'ìd ibn Jubayr from Ibn Abbās [who heard it from the prophet Muhammad]: the first thing that God created, blessed and raised from nothing was the Pen. And he said, »Write!«. He said, »What should I write?« He said, "Write the measures of good and evil.« And he wrote about the world and what existed in it up to the day of Resurrection. ${ }^{37}$

In the Tafsir, in the commentary on Süra 68, 'The Pen`, commenting on the aya 'By the Pen and what they [the angels] writer, al-Tabari cited four similar hadiths beginning: 'The first thing that Allāh created was the Pen $\triangleleft{ }^{38}$ He repeated this statement three times in the History, ${ }^{39}$ although he also noted that other traditionists reported that the first thing to be created was light and darkness. In this way, history was constructed with the aid of the same hadiths that were used in exegesis of the Qur'ann and salvation history came to be recounted in real time.

Yet it is clear that this was almost the end of the road for the writing of this sort of history in Islam. In contrast to Christian chroniclers' deployment of Old Testament narrative in accounts of their own times, the messages of Qur'ān and hadith could only with difficulty be applied to contemporary history. Although Ibn Habib was able to give a providential reading

Al-Ṭabarī, Ta'rīkh, vol. 1, ed. Barth, 187-188, trans. Rosenthal, History of al-Tabari, 357.

Al-Ṭabarī, Ta'rīkh, vol. 1, ed. Barth, 187. 
of the history of al-Andalus, al-Tabarì's account of the caliphs becomes briefer and shorn of isnāds as it approaches his own day, suggesting that after the early years of Islam, the deeds of the caliphs did not seem to be leading to salvation.

Al-Tabari's reputation as a historian remained high, but he was more celebrated than read. Medieval readers preferred to read him in shorter versions shorn of hadith and pages of isnāds, and it was this form that later historians used as the basis for their continuations. An epitome of the work, interpolated as well as condensed, was made within two generations of the historian's death and translated into Persian. ${ }^{40}$ Ibn al-Athì (1160-1233) used al-Ṭabari's work as the basis for his own, extensive history, but he criticised his predecessor for his prolixity. ${ }^{41}$ Yet most of the other Islamic universal histories that Radtke analysed were very different in structure and content. Pre-Islamic and Islamic history were complemented by geography, the history and anthropology of non-Islamic peoples and many other topics - a picture of the world derived from Antique authors translated into Arabic, which Radtke labelled >Kulturgeschichte and which echoes Fredegar's description of his work. ${ }^{42}$ These works are very disparate, the structure and content of each are crucially dependent on the compiler's sectarian position within Islam. ${ }^{43}$ Although many of the sculture historians < focused on cosmology, others did not. Most, but not all, included the biography of Muhammad, but they did not always go on to give an annalistic account of the caliphs. The most famous of these encyclopaedic works are those of the Shìì geographer al-Mas'ùdì (c. 893-956) and of Ibn Khaldūn (1332-1406). ${ }^{44}$ Another Shī‘ì, al-Ya'qūbì (d. c. 905), compiled a miscellany whose first part covered both pre-Islamic history and that of non-Islamic peoples as far afield as India and China. ${ }^{45} \mathrm{Al}$-Mas'ūdī and al-Ya'qübì listed the historians whose works they had consulted; the latter also cited both the Old Testament and the Gospels, either directly or in paraphrase as the >Peoples of the Book, the People of the Gospel and the Christians ${ }^{46}$ Among the later historians, al-Maqdisì (d. 966), a Mu'tazilite, focused on the data that could by confirmed from the Qur'àn, from unbroken chains of isnāds or by the consensus of the Muslim community and condemned the additions that had been made to the stories in the Qur'ān and true hadìth as being likely to lead Muslims into heresy. Yet when al-Maqdisi tried to reconcile accounts of Creation in the different Islamic and non-Islamic traditions, he eventually settled for the non-Arab ('ajam) version of Creation in the Old Testament. ${ }^{47}$ Creation was one aspect of the world that al-Maqdisi was describing rather than the starting point for an eschatological narrative.

Modern historians writing about the early Middle Ages repeatedly try to categorise the sources, perhaps in the hope of making our studies look more scientific. We have assumed that medieval historians too had a mental framework upon which they built their records of the past. As Ian Wood has shown, attempts to uncover this framework, to develop categories such as that of suniversal history < have fundamental flaws and generate outliers: i. e. works

45 Al- Ya'qübī, Ta'rikh.

46 Griffith, The Gospel, the Qur'ann.

47 Khalidī, Mu’tazilite Historiography. 
that will not fit into the proposed classification. Various attempts have been made to ssave the phenomenar: to explain away mismatch between the existing works and our categorisations of them by positing, for instance, that generic conventions did exist even they are difficult to pin down..$^{48}$ For the historians of the medieval Islamic world, too, there were many ways of describing the past, of which a chronological narrative from Creation was only one option. For the two Histories discussed here, and, by inference, during the early centuries of Islam, the primary purpose of writing may have been the extension of the message of the Qur'ann into a chronological account of the past and future of the believers, but after this, providential narratives of the past were subsumed into encyclopaedic enterprises. The differences between the resulting works outweigh any attempt to unite them in a single category of »universal history«.

48 See e.g. Burgess and Kulikowski, Mosaics 9, 13, 16 and passim. 


\section{References}

Burgess, Richard W. and Michael Kulikowski, Mosaics of Time. The Latin Chronicle Tradition from the First Century BC to the Sixth Century AD, vol. 1. A Historical Introduction to the Chronicle Genre from its Origins to the High Middle Ages (Turnhout, 2013).

Christys, Ann, From ğihād to diwān, in: Two Providential Histories of Hispania/al-Andalus, in: M. Di Branco and K. Wolf (eds.), "Guerra santa« e conquiste islamiche nel Mediterraneo (VII-XI secolo), (Rome, 2014) 79-94.

Donner Fred, Narratives of Islamic Origins: the Beginning of Islamic Historical Writings, Studies in Late Antiquity and Early Islam 14 (Princeton, 1998).

Dozy, Reinhart, Recherches sur l'histoire et la littérature des arabes d'Espagne pendant le Moyen Age, 2 vols. (Leiden, 1881).

Franz, Kurt, Kompilation in arabischen Chroniken. Die Überlieferung vom Aufstand der Zang zwischen Geschichtlichkeit und Intertextualität vom 9. bis zum 15 Jahrhundert (Berlin, 2004).

Griffith, Sidney H., The Gospel, the Qur'ann and the presentation of Jesus in al-Ya'qübìs Ta'rïkh, in: John C. Reeves (ed.) Bible and Qurān: Essays in Scriptural Intertextuality (Leiden, 2003) 133-160.

Ibn 'Abd al-Ḥakam, Kitāb futūḥ Miṣr wa-l-Maghrib wa-l-Andalus, ed. Charles C. Torrey (New Haven, 1922).

Ibn al-Athīr, Al-Kāmil fĩ al-tar’îkh, ed. Carl Johan Tornberg, 9 vols, (Leiden, 1853-1867), (reprinted Beirut, 1996) 11 vols.

Ibn Ḥabīb, Ta'rīkh: 'Abd al-Malik ibn Habìb Kitāb al-Ta'rīj, ed. Jordi Aguadé, Fuentes Arábico-Hispanas 1 (Madrid, 1991).

Ibn al-Nadīm, Fihrist: Muhammad ibn Ishāq ibn al-Nadīm, Kitäb al-Fihrist ed. Ayman F. Sayyid (London, 2009), trans. Bayrad Dodge, The Fihrist of Ibn al-Nadim: A Tenth-Century Survey of Muslim Culture (New York, 1970).

Khalidi, Tarif, Islamic Historiography. The Histories of al-Mas'ūdì (Albany, 1975).

Khalidi, Tarif, 'Mu'tazilite Historiography. Maqdisìs Kitāb al-bad' wa-l-ta'rìkh, Journal of Near Eastern Studies 35 (1976) 1-12.

Khalidi Tarif, Arabic Historical Thought in the Classical Period (Cambridge, 1994).

Al-Khushanī: Akhbār al-fuqahā': Muhammad b. Härith al-Jushanī (m. 361/971), Ajbār al-Fuqahā', wa-l-Muhaddithin (Historia de los alfaquíes y tradicionistas de al-Andalus) ed. Mariá Luisa Ávila and Luis Molina, Fuentes Arabico-Hispanas 3 (Madrid, 1992).

Makki Mahmud Ali, Egipto y los origines de la historiografía árabe-española, trans. Michael Kennedy, in: Julio Samsò and Mariá Isabel Fierro (eds.), The Formation of al-Andalus II, Language, Religion, Culture and the Sciences, The Formation of the Classical Islamic World 47 (Aldershot, 1998) 173-233.

Neuwirth, Angelika, Qur'ān and History - a Disputed Relationship. Some Reflections on Qur'ānic History and History in the Qur'ān' Journal of Qur'ānic Studies 5/1 (2003) 1-18.

Newby, Gordon Darnell, The Making of the Last Prophet: a Reconstruction of the Earliest Biography of Muhammad (Columbia, 1989).

Radtke, Bernd, Weltgeschichte und Weltbeschreibung im mittelalterlichen Islam (Beirut, 1992).

Reeves, John C., Some Explorations of the Intertwining of Bible and Qurān, in: John C. Reeves (ed.) Bible and Qurān: Essays in Scriptural Intertextuality (Leiden, 2003) 43-60.

Robinson, Chase F., Islamic Historiography (Cambridge, 2003). 
Shboul, Ahmad M. H., Al-Mas'udi and his World: a Muslim Historian and his Interest in NonMuslims (London, 1979).

Al-Ṭabarī, Ta'rỉkh: Ta'rìkh al-rusul wa-l-mulük, ed. Michael Jan De Goeje et al., 13 vols. (Leiden, 1879-1901); vol. 1 ed. Jakob Barth (1879-81), trans. Franz Rosenthal, The History of al-Tabari (Ta'rikh al-rusul wa'l-muluk), vol. 1, General Introduction and from the Creation to the Flood (Albany, 1989).

Al-Tabari, trans. Hermann Zotenberg, La Chronique. Histoire des prophètes et des rois, 2 vols. (Paris, 1984).

Al-Ṭabarī, Tafsìr ed. Ṣ. al-Khalīdī and I. al-‘Alī, 7 vols. (Damascus, 1997).

Al- Ya'qūbī, Ta'rīkh: Ibn Wādhih qui dicitur al-Ja'qūbì, Historiae, ed. Martijn Theodor Houtsma (Leiden, 1883, reprinted 1969).

Wood, Ian, Universal Chronicles in the Early Medieval West, Medieval Worlds 1/1 (2015) 47-60. Yaqūt, Irshād; Kitäb irshād al-arìb ilà ma'rifat al-adìb, ed. David Samuel Margoliouth (Cairo, 1923). 